\title{
POLITICAL-GEOGRAPHICAL DETERMINANTS OF CONTEMPORARY GEODEMOGRAPHIC CHARACTERISTICS OF BOSNIA AND HERZEGOVINA WITH SPECIAL EMPHASIS TO TERRITORIAL POPULATION DISTRIBUTION
}

DOI: http://dx.doi.org/10.18509/GBP.2019.34

UDC: 314.116-058.64-054(497.15/.6)"1991/2013"

\section{Igor Zekanović}

Departman of Geography, Faculty of Natural Sciences and Mathematics, University of Banja Luka, Bosnia and Herzegovina, Republic of Srpska

\begin{abstract}
Complex political and geographical circumstances in geopolitical space of Bosnia and Herzegovina, in the nineties of the last century, led to the entity division of Bosnia and Herzegovina, according to the criteria of the ethnic majority (Republic of Srpska) and bipolar ethno-geographic structure (Federation of Bosnia and Herzegovina).

When accessing the issue, we start from the premise that contemporary demographic characteristics and processes in $\mathrm{B} \& \mathrm{H}$ have a political-geographical dimension. Mutual conditionality and interaction of political-geographical processes and demographic characteristics condition the sustainability of Bosnia and Herzegovina as a complex geopolitical unit, which is ultimately based on specific ethno-demographic formula $1+2+3$, or more precisely, one country, two entities and three constituent people and religions.

The subject of research in this paper will be essentially based on a comparative analysis of the Census in Bosnia and Herzegovina from 1991 and 2013 and identification of demographic changes in territorial deployment and ethnic structure of the population.

The purpose of this paper is to indicate that the political-geographical processes, military conflicts, specific consequences and recurrence of the war period in Bosnia and Herzegovina in the nineties of the last century had a decisive influence on the contemporary spatial distribution and ethnic composition of the population.

The paper is planned to be realized by general, as well as special methods of geographical research and data processing techniques (statistical, cartographic, graphical, GIS analysis), which are consistent with research of influence of political-geographical processes to contemporary geodemographic characteristics of Bosnia and Herzegovina.
\end{abstract}

Key words: Bosnia and Herzegovina, political-geographical processes, population, ethnic structure, geodemographic characteristics.

\section{INTRODUCTION}

Contemporary political and geographical processes in the world and, in general, events in the international community, in the late $20^{\text {th }}$ and early $21^{\text {st }}$ century, actualized interest in studying the political and geographical content. Today, understanding of political, economic, demographic and other processes in a region or country is not possible without the knowledge of political and geographical content, more precisely, without the knowledge of effect and interaction between "geographical" and "political".

"States, as socio-spatial phenomena, have always been in the centre of interest for political geography. Even today, despite a number of new research topics that we face in 
the study of the relationship of political and spatial phenomena and processes, this is definitely one of the main topics of political and geographical debates, which is not surprising, because states became dominant, the most widespread form of political organization in the world in the last two centuries, and nothing indicates that their role will significantly differ in the future" [1].

Professor Mirko Grčić stated the following: "Geographically, the state may be defined as limited territory, which is organized by the indigenous people, in politically effective manner, with political system that has sovereign control of that territory. Here are three key elements: territory-population-political system (government)" [2].

Together with the territory, population is an essential element of each state. States devote great attention to the population, by implementing measures of population policy. "Its number, spatial distribution, natural movement, structures, migrations, ethnopsychological characteristics, collective historical, cultural-civilization and political heritage, together with territorial features, make the basic elements of the state or some other form of political and territorial organization. Political and geographical valorisation of population characteristics and processes involves analysis of preceding characteristics and synthetic presentation of their importance for the external and internal policy, economy, education, culture, health, defence (or aggression) and other aspects of the functioning of the state or political-territorial community" [3].

Negative demographic processes (insufficient birth rate, departure of working age population and educated population, changes in biological structures of the population, uneven population density, decrease of share of rural population compared to urban, migrants from the Middle East), which are burden for Bosnia and Herzegovina, and their resolution, represent the basic political-geographical issue and the condition for its development as geopolitical unit in geospace of Western Balkans [4].

Therefore, when approaching this issue, we start from the premise according to which geographical-political processes and phenomena represent one of the basic factors and determinant of geodemographic characteristics and demographic development of Bosnia and Herzegovina.

It is necessary to take into account the historical-geographical and geopolitical fact, by which, in relatively recent historical past, federal state system of the second Yugoslavia was based on a model of ethnic federalism, which is not consistently implemented in Bosnia and Herzegovina as a federal unit, composed of the three peoples and three confessions.

If we start from the fact that the destruction of the Yugoslav state and social community was marked by ethnic conflicts about the historical territories and, in the war conflict, entity division of Bosnia and Herzegovina was fixed on the criteria of the ethnic majority (the Republic of Srpska) and multi-ethnic, basically bipolar ethno-geographic structure (the Federation of Bosnia and Herzegovina), than it is logical and objectively justified assumption according to which political-geographical processes and phenomena have the meaning of key factor for its political future.

In this context, we have determined the subject of the research and priorities in the work, which we opereationalize within the standard methodology of analysis and synthesis: demographic, ethno-demographic and ethno-geographic phenomena and structure, as well as on the basis of the relations towards the specific consequences and recurrences of the war period. Due to a number of controversial and unresolved issues, primarily real war victims (unavoidable victimological topic), consequence of the mass refugee and border migrations between the entities and in the immediate environment, and the 
necessity of long-term active population policy in conditions of profound demographic recession, are strategic issues not only of spatial and functional arrangements, but also the functioning of Bosnia and Herzegovina as the political-geographical system[4].

\section{HISTORICAL-DEMOGRAPHICAL CHARACTERISTICS OF BOSNIA AND HERZEGOVINA}

Geospace of Western Balkans is extremely heterogeneous geopolitical, economic and socio-cultural system in which complex cultural and civilization influences intersect. It represents the part of Balkan geospace with the most complex ethno-demographic and religious structure, where the most prominent confrontation of religious-civilizational and cultural influences of East and West is determined by complex political-geographical processes [5].

Table 1. Religious structure of the population of Bosnia and Herzegovina from 1879 to 1931

\begin{tabular}{|cccccccccc|}
\hline \multirow{2}{*}{$\begin{array}{c}\text { Year } \\
\text { of } \\
\text { census }\end{array}$} & $\begin{array}{c}\text { Total } \\
\text { population }\end{array}$ & \multicolumn{2}{c}{$\begin{array}{c}\text { Ortodox } \\
\text { population }\end{array}$} & \multicolumn{2}{c}{$\begin{array}{c}\text { Muslim } \\
\text { population }\end{array}$} & \multicolumn{2}{c|}{$\begin{array}{c}\text { Catholic } \\
\text { population }\end{array}$} & \multicolumn{2}{c|}{$\begin{array}{c}\text { Other } \\
\text { population }\end{array}$} \\
\cline { 2 - 10 }$y$ & & Number & $\%$ & Number & $\%$ & Number & $\%$ & Number & $\%$ \\
\hline 1879 & 1158440 & 496761 & 42.88 & 448613 & 38.73 & 209391 & 18.08 & 3675 & 0.31 \\
\hline 1885 & 1336091 & 571250 & 42.76 & 492710 & 38.88 & 265788 & 19.89 & 6343 & 0.47 \\
\hline 1895 & 1568092 & 673246 & 42.93 & 548632 & 34.99 & 334142 & 21.31 & 12072 & 0.77 \\
\hline 1910 & 1898044 & 825418 & 43.49 & 612137 & 32.25 & 434061 & 22.87 & 26428 & 1.39 \\
\hline 1921 & 1890440 & 829360 & 43.87 & 588173 & 31.11 & 460244 & 24.34 & 12663 & 0.68 \\
\hline 1931 & 2323555 & 1028139 & 44.25 & 718079 & 30.30 & 547949 & 23.58 & 29388 & 1.27 \\
\hline
\end{tabular}

Serbian geographer, Jovan Cvijić, was one of the first scientists who pointed to the political-geographical determinants in ethno-religious characteristics of Bosnia and Herzegovina. One century ago, he stated in his speeches and articles that geospace of Bosnia and Herzegovina is: "the key of Serbian problem, according to the value of the people, according to its central position in the ethnographic mass of Serbian and Croatian people and according to convenient mixture of Orthodox Christians and Catholics" [6]. Census performed in the period of Austro-Hungarian rule, from 1878 to 1910, provide us with the first reliable data about the number of inhabitants and religious affiliation of the population of Bosnia and Herzegovina.

Table 2. National structure of the population in Bosnia and Herzegovina from 1948 to 1991

\begin{tabular}{llllllllll}
\hline $\begin{array}{l}\text { Year } \\
\text { census }\end{array}$ & $\begin{array}{l}\text { Total } \\
100 \%\end{array}$ & Serbs & $\%$ & Croats & $\%$ & Muslims & $\%$ & Other & $\%$ \\
\hline 1948 & 2565277 & 1136116 & 44,3 & 614123 & 23,9 & 788403 & 30,7 & 26635 & 1,1 \\
\hline 1953 & 2847790 & 1264372 & 44,4 & 654229 & 23,0 & 891800 & 31,3 & 37389 & 1,3 \\
& & & & & & $(591800)^{*}$ & 25,6 & $(337389)$ & 7,0 \\
\hline 1961 & 3277948 & 1406057 & 42,9 & 711665 & 21,7 & 842248 & 25,7 & 317975 & 9,7 \\
\hline 1971 & 3746111 & 1393148 & 37,2 & 772491 & 20,6 & 1482430 & 39,6 & 98042 & 2,6 \\
\hline 1981 & 4124256 & 1320738 & 32,0 & 758140 & 18,4 & 1630033 & 39,5 & 415345 & 10,1 \\
\hline 1991 & 4377033 & 1366104 & 31,2 & 760852 & 17,4 & 1902956 & 43,5 & 347121 & 7,9 \\
\hline \multicolumn{7}{c}{ * In census results from the year 1953, Muslims are stated as "Yugoslavs uncommitted“* }
\end{tabular}

According to census data from 1879, in geospace of $\mathrm{BiH}$, there was "1,158,440 inhabitants, of which 496,761 Orthodox Christians (Greek-Orientals), Muslims 448,613 (Mohammedans), Catholics 209,391 (Roman Catholics)" (Table 1, [7]). It was established with second census, from 1 May 1885, that Bosnia and Herzegovina had "1,336,091 inhabitants, of which 571,250 Orthodox Christians, 492,710 Muslims and 
265,788 Catholics" (Table 1, [8]). Period of Austro-Hungarian rule is characterized by a constant increase in population. Serbian population was the leading in the total population potentials, followed by the Muslims at the second place and Catholics at the third place by number (Table 1, [7], [8], [9], [10]).

Numerous population movements between the two world wars are characterized by balanced population growth of Orthodox, Islamic and Catholic population. Orthodox contingent increased from 829,360 to $1,028,139$, Islamic from 588,173 to 718,079 and Catholic from 444,309 to 547,949 inhabitants (Table 1, [11], [12]).

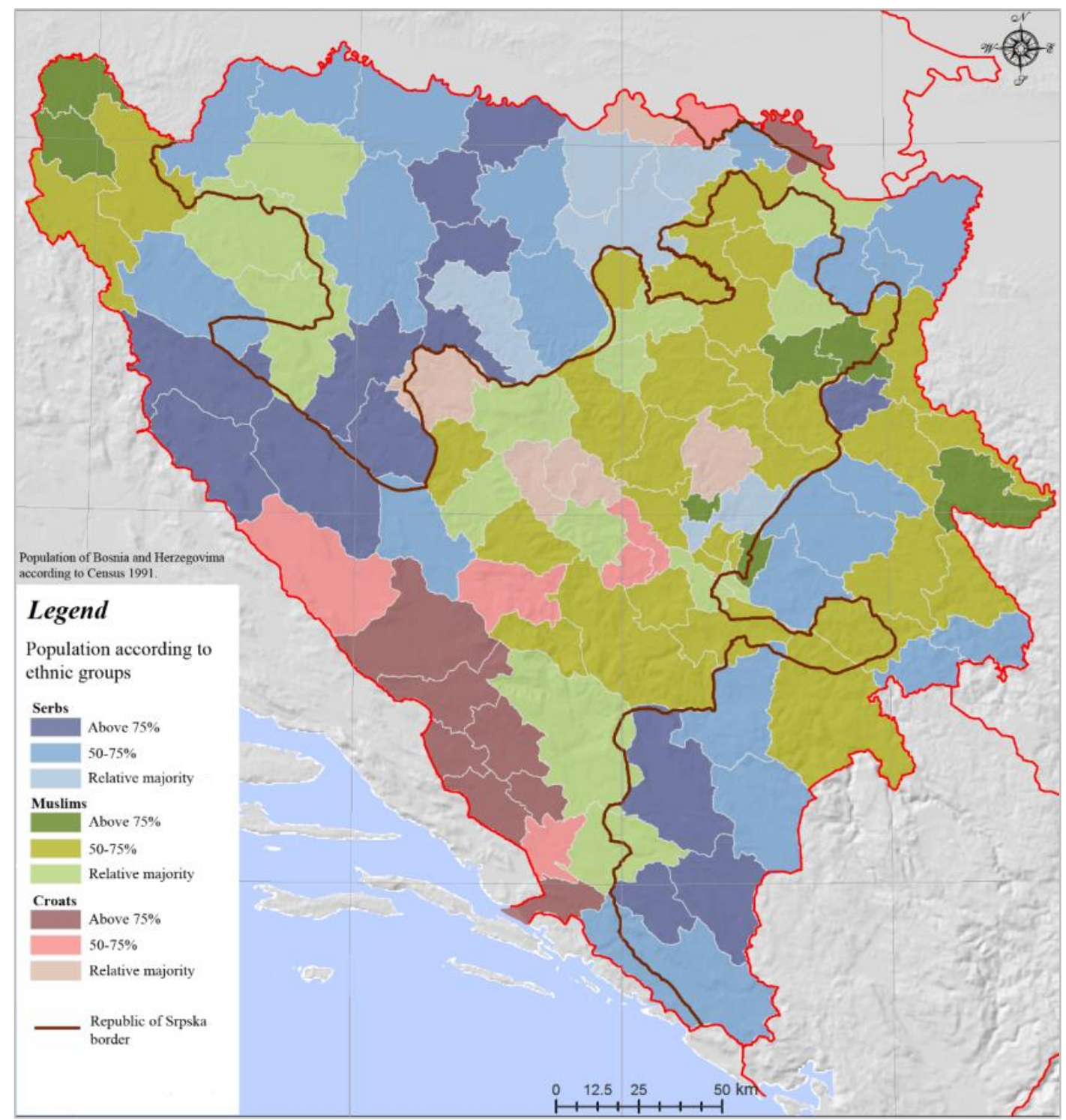

Figure 1. Population by ethnicity/national affiliation according to BiH Census 1991

"Yugoslavian" period between 1945 and 1991 was marked by six censuses $(1948,1953$, 1961, 1971, 1981, 1991). On the basis of the census results from 1948, Bosnia and Herzegovina had 2,565,277 inhabitants. Share of Serbian inhabitants in the total number of population amounted $44.3 \%$ or $1,136,116$ persons. The percentage share of the Muslim population amounted $30.7 \%$, or 788,404 , and Croatian population amounted $23.9 \%$ or 614,123 inhabitants. From 1971, Muslims constituted the largest ethnic group with $1,482,430$ or $39.6 \%$ of the total population (Table 2, [13]). 
According to the last pre-war census from 1991, Bosnia and Herzegovina had 4,377,033 inhabitants: 1,902,956 Muslims (43.5\%), Serbs (31.2\%) and Croats 760,582 (17.4\%) (Table 2, [14]) (Figure 1, [14]).

The religion, as mark of ethnicity and the symbol of belonging to a certain nationality at Western Balkans, and especially in Bosnia and Herzegovina as geospace with the most complex ethno-religious structure, acted in two ways in political-geographical sense: integrative, when it comes to ethnic homogenisation and consolidation of the nation and disintegrative, when it comes to the idea of multi-ethnic and political-territorial communities. The religious factor had a decisive role in the formation of national identity among the people in Bosnia and Herzegovina and definition of their national and politicalgeographical objectives. In these historical and geopolitical circumstances, in geospace of Bosnia and Herzegovina, there are three religions, their languages and letters, customs and traditions, which still leave indelible marks in spiritual and cultural, as well as in historical and geographical dimension of this space [4].

"From 1991 to 2013, there were no official censuses at the territory of Bosnia and Herzegovina. Unreliable statistical records and unrealistic assessment did not provide possibilities for deeper demographic analysis during this period. Census in 2013 showed disappointing results and only confirmed alarming demographic image incurred as a result of various factors in the last two decades" [15].

\section{POLITICAL-GEOGRAPHICAL CONSEQUENCES OF WAR CONFLICTS IN BOSNIA AND HERZEGOVINA ON GEODEMOGRAPHIC CHARACTERISTICS OF GEOSPACE}

Complex political-geographical processes in the world, in the nineties of the twentieth century, among other things, were marked by disintegration of SFR Yugoslavia, which occurred under civil and ethnic-religious conflicts, which escalation was in the geospace of Bosnia and Herzegovina. Bosnia and Herzegovina conflict lasted for three and a half years, and it ended with the signing of the General Framework Agreement for Peace (Dayton Peace Agreement), in November 1995. Bosnia and Herzegovina was created as complex state, unique in the world by its state organization (sui generalis), and it consists of two political-territorial units-entities: the Republic of Srpska and the Federation of Bosnia and Herzegovina. Territory of the pre-war municipality of Brčko was named the district (Figure 2).

The disintegration processes in the geospace of the Western Balkans, in particular military conflicts in Bosnia and Herzegovina, caused a large number of political, economic and other changes, but they had the greatest impact on geodemographic characteristics, specifically in abundance, spatial distribution and the ethnic recomposition of the population in B\&H.

War conflict in geospace "resulted" in direct and indirect demographic consequences, to be more precise, war increased the mortality rate on one hand, and decreased the birth rate on the other hand. There are various estimations of direct demographic losses. Unfortunately, they were based on flat-rate estimation and are not based on empirical research. After more than twenty-three years since the end of war conflict, victimological problems, i.e. the exact number of victims has not yet been determined.

According to estimates of the Ministry of Human Rights and Refugees, "about 250 thousand people lost their lives in the conflict and about 17 thousand are officially registered as missing" [16]. Also, according to estimates by the Research and Documentation Center in Sarajevo (RDC) and the expert in demography at the 
International Criminal Tribunal for the former Yugoslavia in the Hague, Ewa Tabeau direct demographic losses in B\&H are from 97,207 to 104,732 persons [17]. According to elaborated in the expert report for the ICTY in the Hague in 2011, demographer Stevo Pašalić believes that "direct demographic losses in B\&H amount to a minimum of about 110,000 , of which about $29.5 \%$ are Serbs, about $60.5 \%$ are Bosniaks, $8 \%$ are Croats and $2 \%$ other persons"'[17].

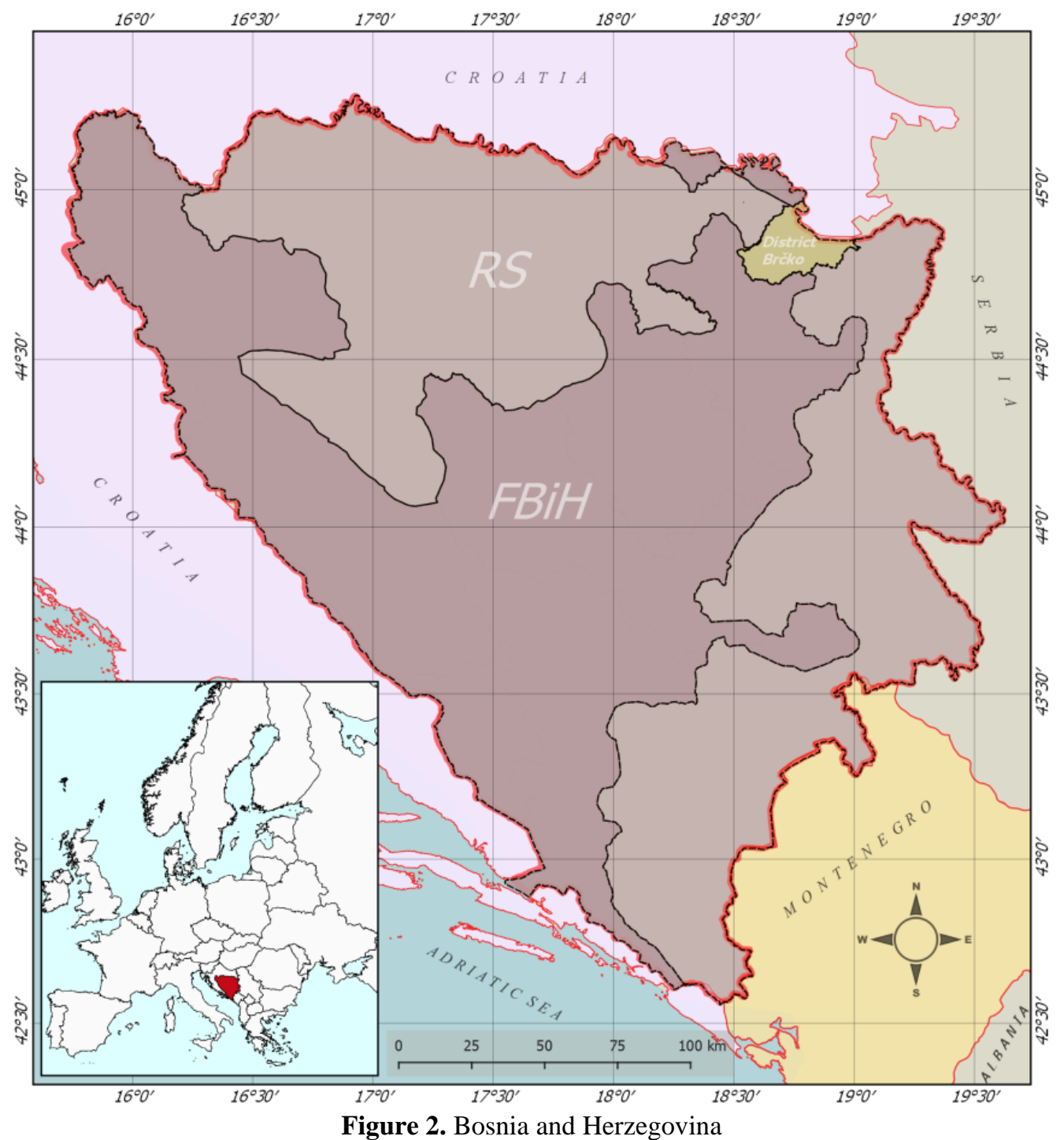

Also, 2.2 million people left their pre-war homes, which amounts more than half of the pre-war population. Approximately 1.2 million persons sought refugee protection in over 100 countries worldwide. In the period 1992-1995 the largest number of refugees from B\&H was registered in the following countries: Germany $(320,000)$, Serbia and Montenegro (297,000), Croatia (170,000), Austria (86,500), Sweden $(58,000)$, Slovenia $(43,000)$, Switzerland $(24,500)$, Turkey $(23,500)$, Netherlands $(22,000)$, USA $(20,000)$, Canada $(20,000)$, Italy $(12,100)$ and Norway $(12,000)$. Around $72.8 \%$ of the total number of refugees was recorded in the first four countries.

At the same time, about one million people were displaced within Bosnia and Herzegovina. Directions of displacement, in the period 1992-1995, were directed in 
accordance with ethnicity, in the areas that were under the control of military forces on ethnic bases [18]. Current of displacement moved towards the places of ethnic majority. The most of displaced persons in the Federation of Bosnia and Herzegovina are Bosniaks, in geospace of the Republic of Srpska they are Serbs, and in the cantons of the Federation, where Croatian population is majority, they are Croats, which confirms the allegations on ethnic homogenization in geospace of $\mathrm{B} \& \mathrm{H}$.

In addition to the demographic destruction, the war radically changed the situation in the housing sector with partial or total destruction of almost half a million of pre-war housing units. Out of this number, about $80 \%$ of housing units were either destroyed or heavily damaged, which is approximately a third of pre-war housing fund [18].

Table 3. Population by ethnic/national affilation 2013.

\begin{tabular}{|ccccccc|}
\hline & & \multicolumn{5}{c|}{ Ethnicity/nationality } \\
\cline { 2 - 7 } Area & Total & Bosniaks & Croats & Serbs & $\begin{array}{c}\text { Did not } \\
\text { declared } \\
\text { Other }\end{array}$ & $\begin{array}{l}\text { No } \\
\text { answer }\end{array}$ \\
\hline Fed. of B\&H & 2219220 & 1562372 & 497883 & 56550 & 98182 & 4233 \\
\hline Republic of Srpska & 1228423 & 171839 & 29645 & 1001299 & 23513 & 2127 \\
\hline Brčko District & 83516 & 35381 & 17252 & 28884 & 1899 & 100 \\
\hline Bosnia and Herzegovina & 3531159 & 1769592 & 544780 & 1086733 & 123594 & 6460 \\
\hline
\end{tabular}

According to data from the "first post-war" Census of Population, Households and Dwellings in Bosnia and Herzegovina, 2013, published by the B\&H Statistic Agency, the total number of inhabitants is 3,531,159. Ethnicity/nationality is as follows: Bosniak population is the largest with $1,769,592$ inhabitants or $50.1 \%$. Serbs follow with $1,086,733$ inhabitants or $30.78 \%$. Croats are the third with 544,780 or $15.42 \%$ of the total number of inhabitants (Table 3, [20]) (Figure 3, [19], [20]).

By analysing ethnic structure in ten cantons of the Federation of Bosnia and Herzegovina, we may conclude that ethno/national principle was crucial within national division. Therefore, out of ten cantos, we have five cantons with Bosniak absolute majority (UnaSana, Tuzla, Zenica-Doboj, Bosnian-Podrinje and Sarajevo Canton). Three cantons have absolute Croatian majority (Posavina, West Herzegovina and Canton 10). Only two cantons do not have ethnic group with absolute majority (Central-Bosnia and Herzegovina-Neretva Canton) (Table 4, [20]), but due to the major urban centers in these cantons, ethnic consolidation and homogenization is also present in these cantons. That is also confirmed by the ethnical structure of the municipalities of: Bugojno and Donji Vakuf (Central-Bosnia Canton) and municipalities of Konjic and the City of Mostar (Herzegovina-Neretva Canton) (Table 5, Author, [20] ).

Changes in ethno-confessional structure are most pronounced on the examples of the cities (Sarajevo, Banja Luka, Mostar) which have the most pronounced ethnic consolidation and homogenisation of the population. Today, these settlements symbolize the centers of national unity of the Bosniak, Serbian and Croatian nation, within which the individual national, ethnic and religious interests are articulated: Sarajevo-Bosniak, Banja Luka-Serbian and Mostar-Croatian.

This is proved by the analysis of the results of Population Census in B\&H in 1991 and 2013. Since the administrative-territorial structure of settlements after the conflict in $\mathrm{B} \& \mathrm{H}$ was changed in relation to the pre-war period, due to precise analysis, settlements from the Table 5, included in the Census 2013, were harmonized with the pre-war administrative-territorial division. Analysis includes 17 administrative centers and about 1,380 settlements in Bosnia and Herzegovina. 
Analysis of these administrative-territorial centers shows the following: compared to 1991, the share of Serbian population in Banja Luka has increased to 58,924 persons, or from $54.6 \%$ to $89.6 \%$ in 2013.

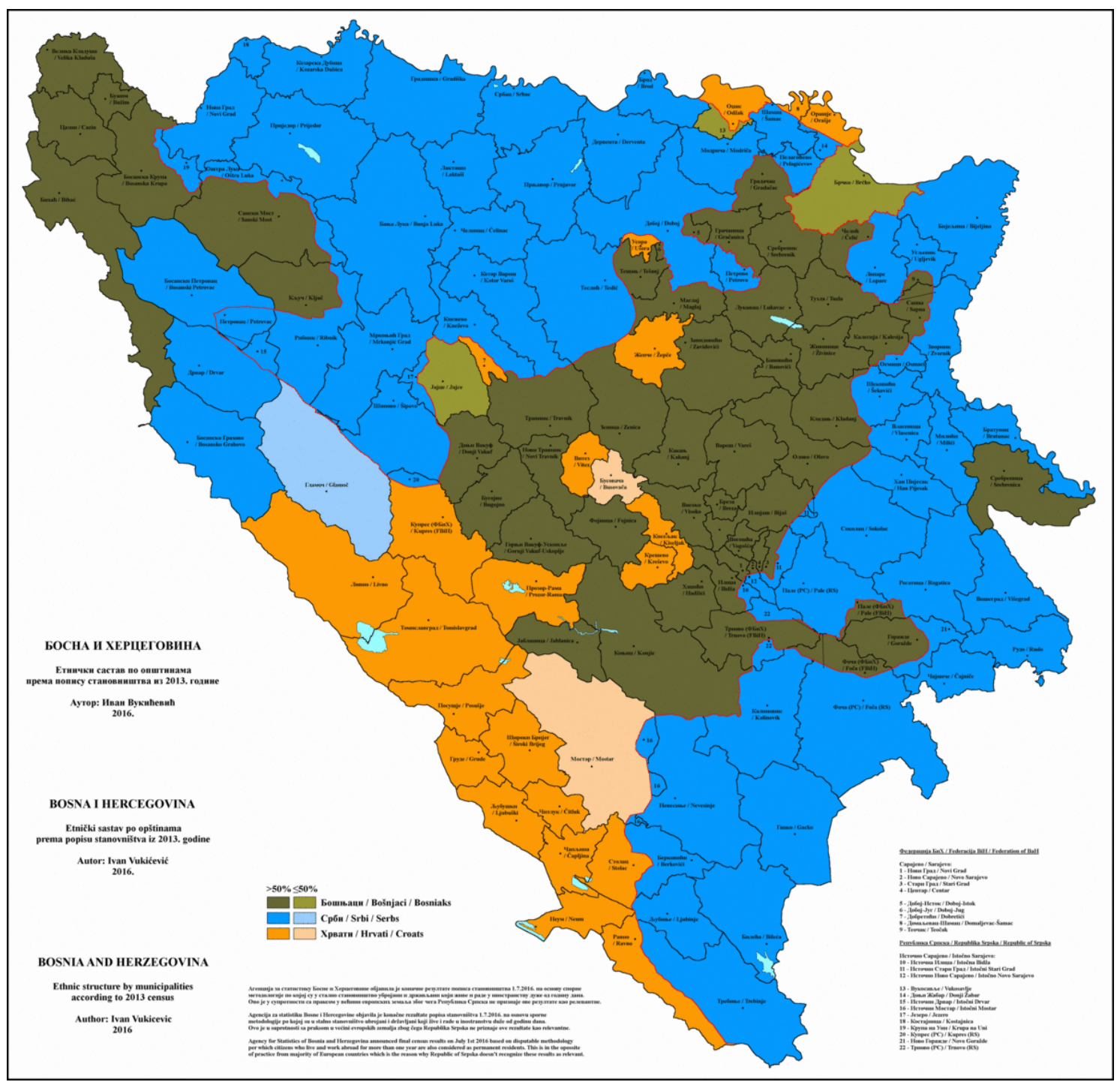

Figure 3. Ethnic distibution according to Census 2013

Table 4. Population by ethnicity/national affiliation in cantons

\begin{tabular}{|cccccc|}
\hline Area/canton & Total & Bosniaks & Serbs & Croats & Other \\
\hline Una -Sana canton & 273261 & 246012 & 8452 & 5073 & 13724 \\
\hline Posavina canton & 43453 & 8252 & 831 & 33600 & 770 \\
\hline Tuzla canton & 445028 & 392356 & 7058 & 23592 & 22022 \\
\hline Zenica-Doboj canton & 364433 & 299452 & 5543 & 43819 & 15619 \\
\hline Bosnian-Podrinje canton & 23734 & 22313 & 885 & 24 & 512 \\
\hline Central Bosnia canton & 254686 & 146652 & 3043 & 97629 & 7362 \\
\hline Herzegovina-Neretva canton & 222007 & 92005 & 6432 & 118297 & 5273 \\
\hline West Herzegovina canton & 94898 & 718 & 101 & 93725 & 354 \\
\hline Sarajevo canton & 413593 & 346575 & 13300 & 17520 & 36198 \\
\hline Canton 10 & 84127 & 8037 & 10905 & 64604 & 581 \\
\hline
\end{tabular}




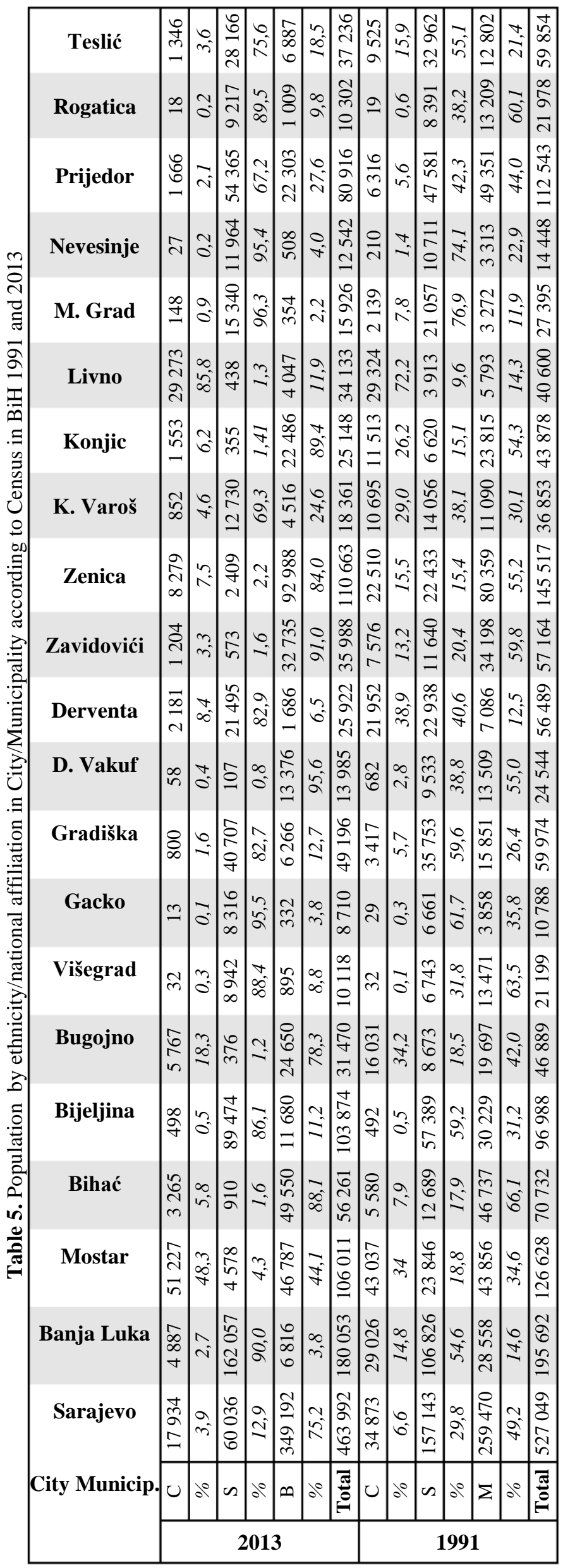


According to Census from 1991, City of Mostar had 126,628 inhabitants, of which 43,856 Muslims, 23,846 Serbs and 43,037 Croats. Today, territory of the former municipality of Mostar has 106,011 inhabitants, of which 46,752 Bosniaks, 4,421 persons of Serbian nationality and 43,037 Croats. Similar situation is in the City of Sarajevo, which had 527,049 inhabitants before the war. There were 259,470 Muslims, 157,143 Serbs, 34,873 Croats and 56,470 Yugoslavs. After the war, the City was divided in administrativeterritorial sense to the City of Sarajevo (Sarajevo Canton) and the City of Istočno Sarajevo (the Republic of Srpska). If we hypothetically joined the Sarajevo Canton and the City of Istočno Sarajevo, according to the Census from 2013, in order to get the territory of the pre-war City of Sarajevo, we would have the total number of 463,992 inhabitants, of which 349, 192 are Bosniaks, 60,036 are Serbs and 17,934 are Croats. Therefore, by ethnic consolidation and homogenisation of the observed geographic space, "there are no" 97,107 Serbs and around 17,000 Croats in Sarajevo.

In 1991, the municipality of Bihać had 70,732 inhabitants. The major ethnic group were the Muslims (Bosniaks) with 46,737 persons or $66.1 \%$ of the total population. The Census from 2013 noted 55,860 inhabitants, and Bosniaks are majority with $88.7 \%$ or 49,547 inhabitants. In the City of Bijeljina, the share of Serbs in the total number of inhabitants, between the last two censuses, was increased from $59.2 \%$ to $85.8 \%$.

Between the last two censuses, the number of Bosniak population in the municipality of Konjic increased from 54.3\% to 89.4\%, as well as in Bugojno from 19,697 persons to 24,650 persons, or to be more precise, from $42 \%$ to $78.3 \%$.

Before the war conflict, the municipality of Gacko had 10,788 inhabitants. Serbs were the most numerous with 6,661 inhabitants or $61.7 \%$. According to Census from 2013, the municipality had 8,990 inhabitants, and number of Serbs amounted 8,556 or $95.2 \%$ of the total population on the territory of the municipality.

The municipality of Gradiška is characterized by similar demographic trends, which in 1991 had 59,974 inhabitants. Serbs were the most numerous ethnic group with 59.6\%. Census from 2013 recorded 51,727 inhabitants, of which 41,863 are Serbs or 80.9\%.

In 1991, Donji Vakuf had 24,544 inhabitants. Muslims (Bosniaks) were the most numerous with 13,509 persons or 55\% of the total population, and in 2013 their share amounted $95.6 \%$ of the total population $(13,376)$.

The following examples also state about the ethnic homogenization. In 1991, the municipality of Zenica had 145,517 inhabitants. Muslims were the most numerous with $55.2 \%$ or 80,359 inhabitants. Census from 2013 recorded 110,657 inhabitants, of which 92,988 are Bosniaks or $84 \%$ of the total population.

On the territory of the former municipality of Prijedor, Muslims were the most numerous with 49,351 inhabitants or 44\%. Serbs follow with 47,581 inhabitants. After the war, in the territory of the City of Prijedor, the most numerous are Serbs with 55,895 inhabitants, which amounts $62.5 \%$ of the total population.

In the municipality of Livno - Croatian population is majority with $85.8 \%$ of share in the total population, unlike in 1991 when it was the majority with $72.2 \%$ (Table 5, [14], [20]). Data from Table 5 indicate that there is inter-entity demarcation in the geospace of Bosnia and Herzegovina, as well as cantonal division based on ethnic principle. These data clearly indicate the political-geographical processes of national homogenization and consolidation during and after the war conflict, as well as the fact that politicalgeographical processes have a strong impact and represent the "axis" of modern geodemographic characteristics of Bosnia and Herzegovina. 


\section{CONCLUSION}

Geospace of Bosnia and Herzegovina is extraordinary complex functionally and complementary, civilization, ethnic and demographic territorial system, in accordance with the position and ethnodemographic characteristics. It is rare occurrence that, in such small naturally and geographically rich and strategically important area, there are three interconnected, and through history, opposed religions. This geospace had its integration and disintegration trends in different historical periods and political-geographical circumstances. That is the reality of this space and all positive and negative changes are reflected to the geodemographic characteristics, whether it is about internal or international changes.

Geodemographic characteristics of Bosnia and Herzegovina are the result of multicentury historical-geographical and political-geographical processes in geospace of the Western Balkans, which had a decisive influence on the dualism in terms of ethnoreligious and cultural mixation on one side and ethno-religious and cultural divergence on the other side.

Therefore, three religions and three nations pervade in centuries of complex historical and geographical circumstances, which left "indelible mark" in the geopolitical dimension of this geospace.

Religious-civilizational determinants of civil, ethnic-religious and fratricidal conflict in Bosnia and Herzegovina influenced the national consolidation and homogenization, and shaped ethnic composition of geospace. In accordance with the provisions of "Dayton Peace Agreement", B\&H is divided according to ethnic principle into entities: the Republic of Srpska with Serbian ethnic majority and the Federation of Bosnia and Herzegovina within which we may find cantons with Bosniak and Croatian majority. The ethnic structure of most urban centers also points to the processes of ethnic homogenization and consolidation in Bosnia and Herzegovina.

\section{REFERENCES}

[1] Bufon, M. Basic of political geography I (Osnove politične geografije I), Department of Geography, Faculty of Philosophy, University of Ljubljana, Slovenia, 2001

[2] Grčić, M. Political Geography (Политичка географија), Faculty of Geography, University of Belgrade, Serbia, 2000

[3] Степић, М. У вртлогу балканизације: Јавно предузеће службени лист СРЈ: Институт за геополитичке студије Београд, Београд, Србија, 2001

[4] Zekanović, I. Ethno-demographic basis of the political-geographic position of the Republic of Srpska (Етнодемографске основе политичко-географског положаја Републике Српске): Geographical Society of Republic of Srpska, Banja Luka, Republic of Srpska, Bosnia and Herzegovina, 2011

[5] Zekanović, I. The influence of global geopolitical processes in the Western Balkans space on interreligious relations and geopolitical stability of Bosnia and Herzegovina (Воздействие глобальных геополитических процессов в Западном Балканском пространстве на межрелигиозные отношения и геополитическую стабильность Боснии и Герцеговины), Научный журнал СОЦИАЛЬНО-ЭКОНОМИЧЕСКАЯ ГЕОГРАФИЯ, ВЕСТНИК АРГО, Ассоциация российских географов-обществоведов (АРГО), Russia, vol 7, pp. 68-79. 2018

[6] Цвијић, Ј. Говори и чланци: Српска Академија наука и уметности, Београд, Југославија, 1991

[7] Štatistika miesta i pučanstva Bosne i Hercegovine, C i Kr. Vladina tiskarna, Sarajevo, 1880 
[8] Штатистика мјеста и житељства Босне и Херцеговине по попису народа од 1. маја 1885, Земаљска штампарија, Сарајево, 1886

[9] Главни резултати пописа житељства у Босни и Херцеговини од 22. априла 1895 , Земаљска штампарија, Сарајево, 1896

[10] Терзић, С. Пројект „аустроугарског Балкана“ у Босни и Херцеговини (О идеолошким основама научних истраживања и научне пропаганде), Зборник радова: Босна и Херцеговина од средњег века до новијег времена, Историјски институт САНУ, Београд, Југославија, стр. 407-423, 1995

[11] Дефинитивни резултати пописа становништва од 31. јануара 1921. год. Краљевина Југославија - Општа државна статистика, Сарајево, 1932

[12] Definitivni rezultati popisa stanovništva od 31. marta 1931. godine, knjiga 2, Prisutno stanovništvo po veroispovesti, Kraljevina Jugoslavija - Opšta državna statistika, Beograd, 1938

[13] Spasovski, M. Živković, D. Stepić, M. Ethnic composition of the population of Bosnia and Herzegovina (Етнички састав становништва Босне и Херцеговине), Faculty of Geography, University of Belgrade, Yugoslavia, 1992

[14] Stanovništvo Bosne i Hercegovine, narodnosni sastav po po naseljima, Državni zavod za statistiku Republike Hrvatske, Zagreb, Hrvatska, 1995

[15] Marinković, D. Majić, A. Population of the Republic of Srpska - demographic factors and indicators - (Становништво Републике Српске - демографски фактори и показатељи -), Faculty of Natural Sciences and Mathematics, University of Banja Luka, Republic of Srpska, Bosnia and Herzegovina, 2018

[16] UPOREDNA ANALIZA PRISTUPA PRAVIMA IZBJEGLICA I RASELJENIH OSOBA, Ministarstvo za ljudska prava i izbjeglice Bosne i Hercegovine, Sarajevo, 2005

[17] Pašalić, S. Demographic losses and demographic development of Serbs as a war consequence in 1992-1995 (Demografski gubici i demografski razvoj Srba kao posljedica ratnih dešavanja 1992-1995), Proceedings: Geopolitical processes in contemporary Euro-Asian space, Geographical Society of Republic of Srpska, Faculty of Science, University of Banja Luka, Republic of Srpska, Bosnia and Herzegovina, pp. 523-542. 2017

[18] Zekanović, I. Changes in demographic and ethno-territorial distribution of BIH polulation as consequence of a violent breakup of former SFRY (Промјене у демографском и етнотериторијалном размјештају становништва БиХ као посљедица насилног распада бивше СФРЈ), Proceedings: Geopolitical processes in contemporary Euro-Asian space, Geographical Society of Republic of Srpska, Faculty of Science, University of Banja Luka, Republic of Srpska, Bosnia and Herzegovina, pp. 543-560. 2017

[19] https://en.wikipedia.org/wiki/Demographics_of_Bosnia_and_Herzegovina

[20] CENSUS Ethnicity/Nationality, Religion, Mother Tongue Book 02. (POPIS, etnička/nacionalna pripadnost, vjeroispovijest, maternji jezik, Knjiga 02), Agency for Statistic of Bosnia and Herzegovina, Bosnia and Herzegovina, 2016 